Małgorzata Ptasińska

Warszawa

\title{
Na marginesie sporu wokół książki Aleksandra Janty-Połczyńskiego Wracam $z$ Polski. List Jana Lechonia do Jerzego Giedroycia z maja 1949 r.
}

Przełom lat czterdziestych i pięćdziesiątych XX wieku był okresem kształtowania się strategii wydawniczej Jerzego Giedroycia po przeniesieniu Instytutu Literackiego z Rzymu do Paryża, po demobilizacji i opuszczeniu wojska. Pierwszoplanowe miejsce w działalności oficyny zajęło wydawanie miesięcznika „Kultura”. Jednak od czasu do czasu J. Giedroyc decydował się na druk książek, które miały się ukazywać w ramach serii Biblioteka „Kultury” od 1953 roku. W dziejach Instytutu Literackiego dochodziło do różnych - miejscami gorących - sporów wokół tekstów publikowanych w „Kulturze” czy w ,Zeszytach Historycznych", a także wydawanych książek. Pierwszym poważnym konfliktem, który unaocznił różnice pomiędzy „,polskim” Londynem a paryską „Kulturą” odnośnie stosunku do powojennej Polski, stała się dyskusja dotycząca reportażu Aleksandra Janty-Połczyńskiego Wracam z Polski $1948[\ldots]$.

Paryska „Kultura” nie uznała porządku pojałtańskiego i od początku konsekwentnie prezentowała jasną postawę wobec kraju - wyrażała sprzeciw wobec podziału kultury polskiej na „emigracyjną” i „krajową”. Uważała, iż przerzucenie pomostu pomiędzy Polakami żyjącymi, tworzącymi i pracującymi w ojczyźnie a emigracją polityczną, która świadomie wybrała swój los, stanowiło jedynie kwestię taktu, zdrowego rozsądku i uczciwego podziału ról ${ }^{1}$. Oddziaływanie na kraj wolnym słowem stało się jednym z filarów linii politycznej J. Giedroycia, pomimo przekonania

${ }^{1}$ Zob. słowa wstępne [Od Redakcji] w dwóch pierwszych numerach czasopisma: „Kultura”, 1:1947, s. 1; 2/3:1947, s. 4-5. 
o nieodwracalności wielu zmian wprowadzonych nad Wisłą. Dyskusję o roli i znaczeniu emigracji, zmierzająca - jak wyraził się Redaktor - do „uświadomienia sobie, o co walczymy i co chcemy przeciwstawić Sowietom i ich ideologii" rozpoczął artykułem Andrzeja Bobkowskiego Pożegnanie w kwietniowym numerze miesięcznika z 1948 roku² $^{2}$.

Jerzy Giedroyc nie poparł wraz z zespołem „Kultury” uchwały Związku Pisarzy Polskich na Obczyźnie z czerwca 1947 roku, która de facto zakazywała twórcom emigracyjnym drukowania w kraju ,utworów swoich dawnych i nowych"3. Sceptycznie odnosił się do poglądów prezentowanych m.in. przez londyńskie „Wiadomości” Mieczysława Grydzewskiego, odrzucające krajową rzeczywistość, krytykujące powroty rodaków, zwłaszcza pisarzy, do ojczyzny. Znamienna dla tego środowiska była postawa ministra informacji i dokumentacji Adama Pragiera wobec osób współpracujących z reżimem warszawskim, sprowadzająca się do potępienia wszelkich przejawów takich kontaktów, a nawet do ostracyzmu, np. wobec Stanisława Mikołajczyka ${ }^{4}$. Zbliżone stanowisko reprezentował Jan Lechoń, który z niepokojem patrzył na zmiany w Polsce, postępująca jej sowietyzację. Wybuch wojny zastał poetę w Paryżu, gdzie skamandryta pełnił obowiązki attaché kulturalnego ambasady polskiej. W 1940 r. po klęsce Francji wyjechał przez Hiszpanię, Portugalię, Brazylię do Stanów Zjednoczonych. W sierpniu 1941 r. osiadł w Nowym Jorku i współuczestniczył m.in. wraz z Kazimierzem Wierzyńskim, Józefem Wittlinem $\mathrm{w}$ formowaniu środowiska literackiego polskich uchodźców, z którego wyrosło Koło Pisarzy z Polski. W tym kręgu zrodził się pomysł wydawania „Tygodniowego Serwisu Literackiego Koła Pisarzy z Polski”,

${ }^{2}$ A. Bobkowski, Pożegnanie, „Kultura”, 6:1948, s. 82-93. A. Bobkowski (19131961) - pisarz, diarysta. Wojnę spędził we Francji, brał udział w działalności francuskiego ruchu oporu. W latach 1945-1948 współpracował z Józefem Czapskim i Samodzielnym Wydziałem Kultury i Prasy przy Delegaturze 2 Korpusu do spraw Uzupełnień we Francji, tzw. placówką paryska. Redagował biuletyn informacyjny, pisał analizy polityczne. Redagował biuletyn informacyjny „Pologne” od czerwca 1946 do czerwca 1948 roku, do wyjazdu do Gwatemali. Z Instytutem Literackim związany od pierwszego numeru „Kultury”. W kraju opublikował w „Twórczości”: Szkice piórkiem (2:1945), Douce France (7-8:1946), Gris moisi (12:1947); w „Nowinach Literackich”: Wiosna w Paryżu (10:1947), Baskijski list (30:1947), Na drogach Francji (37:1947) oraz w „Dziś i jutro” - Pożegnanie (20:1948).

${ }^{3}$ R. Habielski, Życie spoleczne i kulturalne emigracji, [w:] Druga Wielka Emigracja 1945-1990, T. III, Warszawa 1999, s. 155-156.

${ }^{4}$ Zob. Tadeusz Wolsza, Poglady polityczne Adama Pragiera, [w:] Myśl polityczna na wygnaniu. Publicyści i politycy polskiej emigracji powojennej, red. Andrzej Friszke, Warszawa 1995, s. 16-22.

5 Zob. Beata Dorosz, O Lechoniu i Grydzewskim w świetle korespondencji, [w:] Mieczysław Grydzewski, Jan Lechoń, Listy 1923-1956, oprac. B. Dorosz, Warszawa 2006, t. 1, s. 42-57, 129-131. 
następnie - „Tygodniowego Przeglądu Literackiego Koła Pisarzy z Polski”, przekształconego w „Tygodnik Polski”". Pierwszy numer ukazał się w styczniu 1943 roku, a swym charakterem nawiązywał do „Wiadomości Literackich". Po cofnięciu subwencji rządowych przez prof. Stanisława Kota, ministra informacji i dokumentacji rządu polskiego na uchodźstwie, Lechoń objął funkcję redaktora naczelnego od początku 1944 roku. Redakcja poinformowała czytelników o zmianach i uzależnieniu publikacji pisma od uzyskanych prenumerat. Zapewniała jednocześnie: „Nie przerywamy naszej pracy nad skupieniem sił pisarskich, niezależnie od przekonań a złączonych troską o los Polski wolnej, niepodzielnej, demokratycznej i zdolnej do zabezpieczenia swobody i praw wszystkich jej obywateli. Nie przerywamy tej pracy tym bardziej teraz, gdy losy naszego kraju wchodzą w jeden z rozstrzygających okresów wojny"7. W tygodniku obok tekstów skierowanych do Polonii systematycznie pojawiały się doniesienia o sytuacji na froncie, zwłaszcza o losach Armii Polskiej na Wschodzie, a później - 2 Korpusu Polskiego gen. Władysława Andersa. Artykułom z pola walki towarzyszyły utwory między innymi: Jerzego Andrzejewskiego (także pod pseudonimem: Anonimowy Autor z Polski), Władysława Broniewskiego, Konstantego Ildefonsa Gałczyńskiego, Antoniego Słonimskiego czy Leopolda Staffa ${ }^{8}$. Kłopoty finansowe, pomimo zabiegów Lechonia o utrzymanie pisma, spowodowały jego zamknięcie w połowie 1947 roku.

Od 1948 roku Lechoń stale pisywał do „Wiadomości”. Współpracował także z Komitetem Wolnej Europy, powstałym w czerwcu 1949 roku, dzięki czemu poprawiła się wówczas sytuacja materialna poety. Wraz

${ }^{6}$ Zob. Sławomir J. Kowalski, Jan Lechoń jako redaktor i publicysta w okresie nowojorskim, Lublin 1996, s. 21-45; Barbara Czarnecka, Rafał Moczkodan, «Tygodniowy Serwis Literacki Kola Pisarzy z Polski» - «Tygodnik Polski» 1941-1947. Bibliografia zawartości, Toruń 2006, s. 6-14.

${ }^{7}$ Do Czytelników, „Tygodnik Polski”, 54(2):1944, s. 2.

${ }^{8}$ Redakcja pisma w rubryce Opinie $i$ zdarzenia poinformowała czytelników o zamieszczeniu wiersza L. Staffa oraz noweli Przed sadem J. Andrzejewskiego, które były wcześniej drukowane w Polsce - zob. Pisarze z kraju, „Tygodnik Polski”, 159(2):1946, s. 15; B. Czarnecka, R. Moczkodan, dz. cyt., s. 181-202. Czesław Miłosz w swoich raportach z pracy w Ministerstwie Spraw Zagranicznych w Ameryce zauważył: „Lechoń w «Tygodniku Polskim» ogłasza artykuły o «Literaturze polskiej w niewoli», równocześnie jednak uważny czytelnik stwierdzi, że połowę materiału w «Tygodniku Polskim» stanowią przedruki utworów literackich z prasy krajowej (najczęściej bez podania źródła). Należy stwierdzić, że przy natężonej uwadze, z jaką Polacy tutejsi śledzą zjawiska w Kraju, każde wydarzenie kulturalne odbija się tutaj głośnym echem" - Archiwum MSZ, Cz. Miłosz, Raport o nastrojach na terenie działalności Konsulatu generalnego w Nowym Jorku za czas 1 IV-15 V 1946 (poufne). Zob.: Raporty dyplomatyczne Czesława Miłosza, oprac. i przypisy Maria Morzycka-Markowska, posłowie Marek Kornat, Warszawa 2013. 
z K. Wierzyńskim starał się usilnie o przyznanie przez KWE subsydium dla tygodnika M. Grydzewskiego'.

Jerzy Giedroyc nawiązał kontakt z J. Lechoniem i ,Tygodnikiem Polskim" w 1943 roku, kiedy został przeniesiony z Brygady Strzelców Karpackich gen. Stanisława Kopańskiego do Wydziału Informacji i Oświaty Armii Polskiej na Wschodzie, w celu zbierania z różnych ośrodków emigracyjnych materiałów potrzebnych do kierowania Redakcją Czasopism i Wydawnictw Wojskowych ${ }^{10}$. W 1944 roku, w trudnym dla tygodnika momencie, udzielił mu poparcia: „Pragniemy zapewnić Panów, iż pismo Wasze żołnierz polski traktuje jako ważkie narzędzie propagandy Polski, jej literatury i sztuki zarówno wśród społeczeństwa amerykańskiego, jak i milionowej rzeszy Polaków w Ameryce. W emigracji polskiej w St[anach] Zjedn[oczonych]. Widzi on bojowników walki o sprawę polska, a pracę ich dla Polski ma za równie ważną w tej ciężkiej dla nas chwili jak wysiłek walczących na froncie oddziałów"11. Powiadomił również o zebraniu przez żołnierzy czytelników 20 funtów oraz przez redakcję „Orła Białego" - 10 funtów na rzecz „Tygodnika Polskiego"

Parę lat później, kiedy Redaktor założył Instytut Literacki, J. Lechoń ogłosił w „Kulturze” wiersz Nike spod Monte Cassino, poprzedzony tekstem generała Wł. Andersa Cztery lata po bitwie pod Monte Cassino ${ }^{13}$. W końcu listopada 1948 r. skamandryta zastanawiał się również nad opublikowaniem tu Opowiadania Czaplica, rozdziału powieści Bal u senatora, gdy M. Grydzewski miał kłopoty techniczne z zamieszczeniem tego tekstu W „Wiadomościach”14. Na tym jednak zakończyły się kontakty J. Giedroycia i J. Lechonia.

Wkrótce bowiem na łamach „Kultury” Redaktor wydrukował pierwszy fragment reportażu Aleksandra Janty-Połczyńskiego Wracam z Polski, stanowiący zapowiedź książki ${ }^{15}$. Prozaik dużo podróżował po świecie już przed wojną i przesyłał swoje reportaże z odległych zakątków. Zwiedził

${ }^{9}$ Zob. B. Dorosz, O Lechoniu i Grydzewskim..., s. 62-65.

${ }^{10}$ Zob. J. Giedroyc, Autobiografia na cztery ręce, oprac. Krzysztof Pomian, Warszawa 1994, s. 99, 106.

${ }^{11}$ Pismo ppor. Jerzego Giedroycia kierownika Czasopism i Wydawnictw Wojskowych do Redakcji «Tygodnika Polskiego» z dnia 7 marca 1944, „Tygodnik Polski”, 69(17):1944, s. 1.

12 Tamże.

${ }^{13}$ Zob. „Kultura”, 7:1948: Wł. Anders, Cztery lata po bitwie pod Monte Cassino, s. 3-8; J. Lechoń, Nike spod Monte Cassino, s. 5-6.

${ }^{14}$ Zob. B. Dorosz, O Lechoniu i Grydzewskim ..., s. 54.

${ }^{15}$ Zob. Aleksander Janta, Wracam z Polski 1948, „Kultura”, 12:1948, s. 9-24. Wacław Lewandowski (...Strofy dla mew i mgiet... Z dziejów literatury drugiej emigracji (i jej relacji komunikacyjnych), Toruń 2005, s. 45) podaje, iż nie wiadomo, od kogo wyszła inicjatywa napisania książki, gdyż relacje J. Giedroycia i A. Janty się różnią. 
Stany Zjednoczone, ZSSR, Japonię, gdzie był korespondentem „Gazety Polskiej” w latach 1933-1934. Następnie także jako reporter wyjechał do Abisynii. Odwiedził Indie, Afganistan, Birmę, Tajlandię, Chiny, Tajwan, Mongolię. Wojna zastała go w Paryżu, brał udział w walkach 1 Dywizji Grenadierów w Wogezach. Nadsyłał relacje do „Głosu Polskiego”, „Polski Walczącej”, „Wiadomości Polskich”. Po kapitulacji Francji w 1940 r. dostał się do niewoli i pod przybranym nazwiskiem: René Lapédagne przebywał w obozie dla jeńców francuskich ${ }^{16}$. W 1943 roku - po wielu perypetiach - dotarł do Londynu. Swoje przeżycia z tego okresu opisał w książce Kłamałem, aby żyć. Wiosną 1944 r. wyjechał jako korespondent wojenny do Nowego Jorku, a „Tygodnik Polski” donosił o przyjeździe dziennikarza ${ }^{17}$. W Księdze Gości J. Lechonia publicysta zapisał: „Janta wrócił. New York April 1st 44”18. Ponownie udał się do Europy, by walczyć w 1 Dywizji Pancernej w Belgii i Holandii. W 1945 r. osiadł na stałe w Stanach Zjednoczonych. Drukował wówczas m.in. w „Dzienniku Polskim i Dzienniku Żołnierza”, „Tygodniku Polskim”.

Aleksander Janta wyjechał do Polski na trzy miesiące w lipcu 1948 r. jako dziennikarz zagraniczny „Life'u” i agencji odczytowych, m.in. Agencji Charlesa S. Pearsona ${ }^{19}$, ale z polskim paszportem konsularnym ${ }^{20}$. Zanim jednak pisarzowi udało się odbyć tę podróż, dwa lata wcześniej nawiązał kontakt z czasopismami krajowymi i opublikował nowelę Podstuch w „Twórczości”, a rok przed podróżą wydał Kłamałem, aby żyć w Spółdzielni Wydawniczej „Wiedza”21. Złamanie przez prozaika uchwa-

${ }^{16}$ Zob. Janusz Odrowąż-Pieniążek, Działalność Aleksandra Janty-Połczyńskiego, [w:] Polskie środowiska twórcze na emigracji we Francji wrzesień 1939-czerwiec 1940, pod red. Michała Tymowskiego, Warszawa 1995, s. 127-136.

${ }^{17}$ Zob. Janta w Nowym Jorku, ,Tygodnik Polski”, 65(13):1944, s. 14.

${ }^{18}$ Księga gości Jana Lechonia, oprac. B. Dorosz, Toruń 1999, s. 76.

${ }_{19}$ Zob. Jerzy Giedroyc, Melchior Wańkowicz, Listy 1945-1963, oprac. Aleksandra Ziółkowska-Boehm, Jacek Krawczyk, Warszawa 2000, s. 62.

${ }^{20}$ Zob. Franciszek Palowski, Aleksander Janta-Połczyński. Ballada o wiecznym szukaniu, Kraków 1990, s. 75; A. Janta, Nowe odkrycie Ameryki, Paryż 1973, s. 108.

${ }^{21}$ Czesław Miłosz w zamieszczanych w raportach relacjach ze swoich rozmów z emigrantami w Ameryce napisał o Jancie: „Politycznie związany jest z przeciwnym obozem, jednak można z nim rzeczowo dyskutować i akceptuje reformy dokonane w Polsce. Wyraził chęć jazdy do Polski i pytał, czy można pojechać na jakiś czas, bo przed wojną do Polski też przyjeżdżał na krótko, jeżdżąc po całym świecie jako korespondent „Wiadomości Literackich". Jest on bardzo dobrze wprowadzony w Ameryce i ma duże stosunki w Indiach. Jest zainteresowany wydaniem swojej książki w Polsce: „Kłamałem, aby żyć” (pobyt w niewoli niemieckiej pod cudzym nazwiskiem francuskiego szeregowca). Ukazało się to tutaj po polsku i angielsku. Na literatach robi dobre wrażenie wysokość nakładu i natychmiastowe rozkupowanie książek ukazujących się w kraju" - Archiwum MSZ, Cz. Miłosz, Sprawozdanie z czynności za czas od 7 II 1946-30 III 1946 z działu kultury i sztuki (poufne). Zob.: Raporty dyplomatyczne Czesława Miłosza, oprac. i przypisy Maria Morzycka-Markowska, posłowie Marek Kornat, Warszawa 2013. 
ły ZPPnO wywołało protest m.in. Wacława Grubińskiego i Tymona Terleckiego ${ }^{22}$. Nie wpłynęło jednak na relacje pisarza z polskimi uchodźcami w Nowym Jorku, zwłaszcza z J. Lechoniem, z którym znał się jeszcze sprzed wojny ${ }^{23}$. Aleksander Janta nadal publikował też w „Wiadomościach", a swoim tekstem Nowojorski jubileusz. O Lechoniu jubileuszowym uświetnił w tygodniku M. Grydzewskiego 30-lecie napisania przez poetę Karmazynowego poematu ${ }^{24}$.

W sierpniu 1946 r. zadebiutował w „Wiadomościach” Zbigniew Florczak $^{25}$, żołnierz AK, uczestnik powstania warszawskiego w zgrupowaniu pułku „Baszta”. Po wygaśnięciu zrywu trafił do obozu jenieckiego w Sandbostel koło Bremy. Następnie, już po wojnie, zamieszkał w Brukseli $^{26}$. Tu ukończył królewską Akademię Sztuk Pięknych i szkołę dziennikarstwa, ponadto zajmował się wraz z Antonim Bormanem i Janem Czarnockim sprawami druku tygodnika M. Grydzewskiego w „La Colonne”27. W styczniu 1947 r. na pierwszej stronie „Wiadomości” zamieszczono tekst Z. Florczaka Błędne lustro, podważający sens wybuchu powstania warszawskiego i wzbudzający tym samym wiele polemik ${ }^{28}$. Kontrowersyjny artykuł nie zakończył współpracy eseisty z tygodnikiem, w którym dalej mógł publikować ${ }^{29}$. Edmund Goll wspominał nawet o planach A. Bormana i redaktora „Wiadomości”, którzy w Z. Florczaku widzieli kandydata na następcę Grydzewskiego ${ }^{30}$. Na pierwsze teksty felietonisty

\footnotetext{
${ }^{22}$ Zob. F. Palowski, dz. cyt., s. 71-74.

${ }^{23}$ Zob. Księga gości Jana Lechonia, s. 13, 56.

${ }^{24}$ Zob. A. Janta, Nowojorski jubileusz. O Lechoniu jubileuszowym, „Wiadomości”, 24:1948, s. 3; M. Grydzewski, J. Lechoń, dz. cyt., s. 169-170.

${ }^{25}$ Zob. Zbigniew Florczak, Dwie koncepcje wojny, „Wiadomości”, 19:1946, s. 3. Zbigniew Florczak (1923-2005) - publicysta, eseista, krytyk sztuki, tłumacz. W końcu 1947 r. ze względów osobistych wystapił o polski paszport, został nauczycielem konsularnym, skierowanym do pracy najpierw w Quaregnon, a później w Moignelée - zob. tenże, Podróż na horyzonty, Warszawa 1966, s. 213-231. W 1948 r. wyjechał z dziećmi emigrantów na trzymiesięczne wakacje do kraju, organizowane przez polski konsulat (zob. tamże, s. 231-246). Wiosną 1949 r. rozpoczął starania o IRO - status uchodźcy, które zakończyły się niepowodzeniem. Giedroyc wystawił nawet pisarzowi zaświadczenie dla IRO w Belgii, poświadczające jego współpracę z „Kulturą” - zob. Archiwum Instytutu Literackiego Maisons-Laffitte (dalej: AIL ML), J. Giedroyc do Z. Florczaka, 2 V 1949 r. W grudniu 1949 r. Z. Florczak powrócił do Polski.

${ }^{26}$ Zob. Z. Florczak, Podróż na horyzonty, s. 5-10.

${ }^{27}$ Zob. Mirosław Adam Supruniuk, Pracowita nieobecność (Prace redakcyjne Mieczystawa Grydzewskiego w latach 1944-1947. Próba reaktywowania ,,Wiadomości”), [w:] ,,Wiadomości” i okolice. Szkice $i$ wspomnienia, t. 1, red. i opr. M.A. Supruniuk, Toruń 1995, s. 56.

${ }^{28}$ Zob. Z. Florczak, Lustro błędu, „Wiadomości”, 43:1947, s. 1.

${ }^{29}$ W „Wiadomościach” Z. Florczak zamieścił ponadto: Wstęp do ksiażki (84:1947), s. 2; Koestler w Soplicowie (161:1949), s. 1.

${ }_{30}$ Zob. Edmund Goll, Składatem „Wiadomości” w Brukseli, [w:] „,Wiadomości” i okolice, dz. cyt., s.158-159.
} 
z Brukseli zareagował Gustaw Herling-Grudziński, który powinszował mu zwłaszcza Blędnego lustra i na poczattu 1947 r. zaproponował pisanie do „Kultury”31. Propozycję tę powtórzył J. Giedroyc w końcu listopada tegoż roku, po przeniesieniu Instytutu z Rzymu do Paryża ${ }^{32}$. Tymczasem Z. Florczak przesłał do „Kultury” swój pierwszy artykuł - Rozstanie ze sztuka i w ten sposób rozpoczął współpracę z pismem ${ }^{33}$. Podobnie jak A. Janta trzy miesiące spędził w Polsce, gdzie doszło do spotkania obydwu publicystów w Warszawie, w siedzibie $\mathrm{YMCA}^{34}$. W trakcie rozmowy powstał projekt napisania przez Z. Florczaka artykułu na marginesie książki A. Janty, do której ten ostatni zbierał materiały ${ }^{35}$.

We słowie wstępnym do Wracam z Polski A. Janta zaznaczył, że poprzednio był w ojczyźnie dziewięć lat temu, nie przeżył Września, okupacji ani powstania warszawskiego. Samą decyzję o wyjeździe pisarz uzasadniał tym, że przestało mu wystarczać ,,widzenie sytuacji w Polsce poprzez filtry poglądów emigracji” ${ }^{36}$. Wyjaśniał dalej: ,wracam dzisiaj po odbytej podróży, z dokonania której nie widzę potrzeby tłumaczenia się przed kimkolwiek. Pozostałem wierny swojemu sumieniu i swemu zawodowi - powodowała mną troska o sprawy wspólne Polakom i wspólne ludziom [...]. Powodowała mną ciekawość poznania na własną rękę nowej polskiej rzeczywistości, jakakolwiek by ona była. Zdaję sobie sprawę, że ten rodzaj reportażu, jakiego podejmuję się dziś, w okresie podniecenia ideologicznego i zacietrzewień, w jakich żyjemy po obu stronach kurtyny, nie będąc $\mathrm{w}$ stanie mówić o sobie inaczej jak tylko z pianą gniewu na ustach, jest nie tylko trudnym, ale także niewdzięcznym zadaniem. Proszę jednak czytelnika o niewyciaganie zbyt pochopnych wniosków zanim nie przeczyta całości" ${ }^{37}$.

Tekst wywołał burzę w środowiskach emigracyjnych, a na „Kulturę” spadła fala krytyki. Na polecenie gen. Andersa w Wielkiej Brytanii pismo wycofano ze sprzedaży, a Zarząd Związku Pisarzy Polskich na Obczyźnie wystosował swój protest przeciw tej publikacji ${ }^{38}$. Jerzy Giedroyc zde-

\footnotetext{
${ }^{31}$ Zob. Z. Florczak, Podróż na horyzonty, s. 172.

${ }^{32}$ Zob. AIL ML, J. Giedroyc do Z. Florczaka, 24 XI 1947 r.

${ }_{33}$ Zob. Z. Florczak, Rozstanie ze sztuka, „Kultura”, 2/3:1947, s. 69-75. Zob. także AIL ML, Z. Florczak do J. Giedroycia, 6 I 1948 r.

${ }^{34}$ Zob. Z. Florczak, Podróż na horyzonty, s. 247-248.

${ }^{35}$ Zob. tamże, s. 247. Mowa o: Z. Florczak, Examen libre, „Kultura”, 2(19):1949, s. $3-12$.

${ }^{36}$ A. Janta, Wracam z Polski $1948 \ldots$, s 9.

${ }^{37}$ Tamże, s. 10-11.

38 O opinii ZPPO jako pierwszy doniósł nieprzychylny Instytutowi „Bywalec” z „Dziennika Polskiego i Dziennika Żołnierza” (25:1949, ). W artykule poinformowanorównież, że Gustaw Herling-Grudziński oraz Tadeusz Sułkowski zrezygnowali z pracy
} 
cydował o wstrzymaniu druku następnych fragmentów, a w kolejnym numerze pisma opublikował oświadczenie, w którym zadeklarował wydanie dalszego ciągu reportażu własnym nakładem. Podkreślił funkcję poznawczą artykułu, który pozwał skonfrontować aktualne obserwacje emigracyjnego reportera $\mathrm{z}$ opiniami głoszonymi poza krajem o zachodzących tam przemianach. Zdaniem Redaktora można było się nie zgadzać z tak daleko idącymi sformułowaniami A. Janty, należało się jednak w nie wsłuchać, ponieważ ,jest naszym najważniejszym obowiązkiem te zmiany wyczuwać, obserwować i wyciagać z nich wnioski dla swego działania. Naród jest bowiem dla nas jedynym sensem naszego tu istnienia" 39 . Jerzy Giedroyc wyraził swe rozczarowanie brakiem rzetelnej dyskusji, zastapionej ,„śliskimi insynuacjami, wołaniem o policjanta i cenzora" ${ }^{40}$. Dobitnie stwierdził: „Nie jesteśmy pismem propagandowym, operującym sztancami. Jest zbyt wiele zagadnień w życiu polskim drażliwych i wstydliwych, których się nie wyjaśnia ani rozwiązuje, pokrywając je natomiast wyświechtanym frazesem. [...] Jakkolwiek bardzo często krytykujemy na łamach «Kultury» jałowość czy dekadencję Zachodu, to jednak dlatego jesteśmy z nim, że tu jest wolność, bez której żadna twórcza dyskusja o Polsce jutra nie jest możliwa"41.

Na przełomie października i listopada 1948 r. doszło do wymiany listów pomiędzy J. Czapskim, gen. Andersem a J. Giedroyciem w sprawie Wracam z Polski ${ }^{42}$. Każdy z nich zaprezentował własny punkt widzenia w tej kwestii, co jednak nie zbliżyło stron. Pierwszy napisał J. Czapski do generała $z$ thumaczczeniem, że artykuł ze wstępem mu się nie podobał i nie zamierza bronić tekstu. Pragnął jednak wyjaśnić adresatowi taktykę Redaktora, „który dotychczas rozumiał swoją odpowiedzialność w tym, że powinien stać bezwzględnie na stanowisku niepodległościowym, lecz że wolno mu prowadzić taktykę miesięcznika wolnego, który nie jest «urzędówką» jak «Orzeł»"43. Podkreślił, że czasopismo jest skierowane do inteligencji. Józef Czapski prosił gen. Andersa o odwołanie konfiskaty „Kultury” w Londynie i zgodę na publikację drugiej części reportażu. Swoje stanowisko uzasadnił szczególną pozycją tego periodyku na emi-

w Zarządzie domagając się zajęcia bardziej krytycznego stanowiska wobec decyzji Gryfu, kolportera wydawnictw Instytutu Literackiego w Wielkiej Brytanii.

39 [J. Giedroyc], [Od Redaktora], „Kultura”, 13:1948, s. 11-12.

40 Tamże.

${ }^{41}$ Jak wyżej.

${ }^{42}$ Zob. Małgorzata Ptasińska, Czapski-Anders-Giedroyc. Trzy listy w sprawie Janty, „Zeszyty Historyczne”, 138:2001, s. 78-97; taż, Z dziejów Biblioteki «Kultury» 19461966, Warszawa 2006, s. 80-107.

${ }^{43}$ AIL ML, J. Czapski do gen. W. Andersa, 29 X 1948 r. 
gracji oraz tym, że pismo dociera do wielu krajów na całym świecie. Uważał, iż w tej sytuacji wstrzymanie druku dalszych fragmentów mogłoby „stworzyć najbardziej szkodliwą plotkę ideologicznych zakłamań z jednej strony czy «faszystowskich» metod emigracji. Kapitał, który «Kultura» zdobyła i za granica, i w kraju, może przepaść" ${ }^{44}$. Pisarz poinformował generała, że J. Giedroyc jako uzupełnienie reportażu A. Janty planuje zamieścić relację człowieka, który również przybył z kraju i przez całą wojnę należał do AK. Choć J. Czapski osobiście uważał wydrukowanie tekstu A. Janty za błąd, swój list zakończył deklaracją: „Niemniej jednak z całą linią pisma z jej wysiłkiem, by się emigracja nie wyobcowała z Polski - solidaryzuję się na tyle, że uważam tę linię za moją również, dlatego nie umiałabym uchylić się od odpowiedzialności za całokształt pracy Redaktora, a więc i za ostatni artykuł. Dlatego będę czekał z największą niecierpliwością na odpowiedź Pana Generała"45.

W tym samym czasie gen. Anders skierował do J. Giedroycia list, w którym wyraził swoje zdziwienie opublikowaniem reportażu A. Janty. Uznał artykuł za ,jaskrawo sprzeczny z poglądami naszego obozu, a nawet podający w wątpliwość słuszność naszej walki o Polskę Niepodległa" ${ }^{46}$. Szczegółowo zanalizował i negatywnie ocenił tekst $\mathrm{Wra}$ cam z Polski, m.in. zarzucił autorowi kilkakrotne użycie bez cudzysłowu wyrazu ,wyzwolenie”. Na koniec generał poinformował o swojej decyzji wstrzymania w Anglii sprzedaży i wysyłki prenumeratorom dwunastego numeru „Kultury”, a także o niezwłocznym całkowitym wycofaniu tego numeru $\mathrm{z}$ dalszej sprzedaży $\mathrm{w}$ innych miejscach. Nie zezwolił też na drukowanie dalszego ciagu reportażu A. Janty, gdyż chciał postawić tamę dyskusjom publicystycznym i wciaganiem polskich środowisk niepodległościowych „w oślizgłą atmosferę ideologiczną"47. Zdaniem gen. Andersa opublikowanie tego tekstu, po wcześniejszym artykule A. Bobkowskiego ${ }^{48}$, stanowiło drugi epizod, który mógłby „,rzucić niepożądane światło na zawartość i czystość ideologiczną polskiego Obozu Niepodległościowego, a sprawa jest szczególnie ważna w obliczu nadchodzących chwil przełomowych - proszę Pana Redaktora, aby w przyszłości, w wypadku posiadania artykułu przeznaczonego do druku w «Kulturze», który by wywoływał wattpliwości z punktu widzenia politycznego, projektowany artykuł był mi przesłany do oceny"49.

\footnotetext{
${ }^{44}$ Tamże.

${ }^{45}$ Tamże.

${ }^{46}$ AIL ML, Gen. W. Anders do J. Giedroycia, 30 X 1948 r.

${ }^{47}$ Tamże.

${ }^{48}$ Zob. A. Bobkowski, Pożegnanie, „Kultura”, 6:1948, s. 82-93.

${ }^{49}$ AIL ML, gen. W. Anders do J. Giedroycia, 30 X 1948 r.
} 
W odpowiedzi J. Giedroyc zapewnił gen. Andersa o swojej lojalności i wdzięczności za pomoc przy tworzeniu Instytutu Literackiego. Podkreślił, że choć nie należał do najbliższego otoczenia generała, zawsze postępował zgodnie z wytycznymi obozu niepodległościowego. Odpierał zarzuty o rozkładaniu emigracji i sianiu pesymizmu, argumentował, że w epoce szalejącej propagandy i zakłamania szczerość oraz obiektywizm stanowią najskuteczniejszą taktykę polityczną. Wyjaśnił generałowi, że widzi „Kulturę” w roli „trybuny, wyprutej z jakichkolwiek akcentów propagandowych, której zadaniem byłoby poruszanie i dyskutowanie wszystkich najważniejszych problemów ideologicznych, nawet najbardziej drażliwych, uważając bardzo starannie, by nie wiązać się z żadnym ruchem, stronnictwem czy kierunkiem"50. Dalej Redaktor podkreślił pozycję, jaką pismo zyskało na wychodźstwie oraz w Polsce. Dzięki kontaktom z krajem on sam zrozumiał przyczyny niechęci rodaków do emigracji, która zwalczając reżim komunistyczny, nie umiała odróżnić go od społeczeństwa i zbagatelizowała jego wysiłek włożony w odbudowę ojczyzny ze zniszczeń wojennych. Zdaniem J. Giedroycia mieszkańcy Polski obawiali się „emigracji jako wstecznej, żyjącej tylko wizją Polski sprzed 1939 r., a wizja ta Krajowi nie odpowiada"51.

Redaktor wyjaśniał, że opublikowanie reportażu A. Janty miało na celu przekonanie rodaków nad Wisłą, iż emigracja dostrzega ich trud i jest w stanie zdobyć się na obiektywną ocenę sytuacji w kraju. Natomiast wychodźstwu pokazano społeczeństwo polskie podlegające przemianom, których nie można ignorować. Jerzy Giedroyc przyznał, że w tekście znalazło się wiele niezręcznych sformułowań, które stanowiły bardziej niedopatrzenie przy adiustacji niż ,wyraz entuzjazmu dla reżimu warszawskiego" ${ }^{52}$. Broniąc zarówno autora, jak i prawa do swobodnego kształtowania własnego pisma, Redaktor wyznał, że zarządzenie generała było dla niego moralnie i prestiżowo bardzo ciężkie, ponadto przyniosło więcej szkody niż pożytku. Rozdmuchanie całej sprawy do niebotycznych rozmiarów stworzyło posmak skandalu i dało argumenty przeciwnikom. „Rozumiejąc to dobrze - konkludował J. Giedroyc - zrobiłem wszystko, by sprawę załatwić bez powiększenia tego skandalu i by całkowicie wyeliminować osobę Pana Generała. Zrobiłem to z bardzo ciężkimi dla mnie poświęceniami i najlepiej, jak mogłem. Pragnę na zakończenie jeszcze zwrócić uwagę Pana Generała, że jestem z całym szacunkiem dla stanowiska p. Janty, który w tej całej sprawie został najmocniej zaatakowany, a będąc

${ }^{50}$ AIL ML, J. Giedroyc do gen. W. Andersa, 8 XI 1948 r.

51 Tamże.

${ }^{52}$ Tamże. 
człowiekiem całkowicie niezależnym i mając duże możliwości nie tylko polskie, ale i amerykańskie, bez najmniejszego nawet $\mathrm{z}$ mojej strony nacisku zrezygnował z poruszania tych spraw publicznie" 53 .

Zgodnie z zapowiedzią Redaktor wydał Wracam z Polski 1948 (Warszawa-Wrocław-Kraków-Poznań-Szczecin-życie-polityka-gospodarka-sztuka-ludzie i zagadnienia) A. Janty własnym nakładem na początku 1949 r. w liczbie 2 tys. egzemplarzy, bez sygnetu oficyny. W trakcie prac redakcyjnych nad książką doszło do pewnych nieporozumień dotyczących niektórych jej fragmentów. Jerzy Giedroyc zwrócił autorowi uwagę na szereg sformułowań, które były ,prowarszawskie” lub mogły za takie uchodzić. Przypisał je pośpiechowi i trudnościom w pisaniu reportażu. Jednak ostatnie poprawki zaniepokoiły Redaktora, uznał je za ,zabarwione już wyraźną tendencja" ${ }^{54}$ i odmówił A. Jancie ich wprowadzenia, grożąc wycofaniem książki z druku. „Staram się - tłumaczył autorowi - patrzeć na zagadnienie polskie najbardziej z punktu widzenia ogólnego, a nie czysto nacjonalistycznego, ale wydaje mi się, że zawsze trzeba - specjalnie w warunkach polskich - odróżniać agentów i agentury i nie mieszać ich z polityką"55.

Konflikt udało się zażegnać i uspokojony J. Giedroyc w pierwszych dniach stycznia powiadomił pisarza o końcowych pracach nad książka, zapowiedział jej szybkie wydanie i zapewnił go o swoim całkowitym zaufaniu, gdyż inaczej nie angażowałby się we współpracę. „Musi Pan - pisał - wziąć pod uwagę, że w tym straszliwym zakłamaniu propagandowym, w jakim i emigracja, i kraj żyją - Pana książka jest ogromnym wstrząsem dla czytelnika. Nie należy przesadzać dawki, dlatego że to może dać skutek wręcz odwrotny od zamierzonego" "56. Redaktor wyjaśniał też autorowi, dlaczego pozwolił sobie na tak duże ingerencje w tekst: „Chciałbym, żeby Pan wierzył, że robiłem je i ze względu na efekt polityczny, jak również ze względu na Pana, gdyż szkoda by było, aby pewne niezręczności taktyczne naraziły Pana na ostracyzm"57.

Książka A. Janty stała się przedmiotem gorących dyskusji na łamach „Wiadomości”, które wystapiły z ostrą krytyką autora i wydaw$\mathrm{cy}^{58}$. Z grona tygodnika J. Lechoń zareagował najbardziej emocjonalnie,

${ }^{53}$ Jak wyżej.

${ }^{54}$ AIL ML, J. Giedroyc do A. Janty-Połczyńskiego, 16 XII 1948 r.

55 Tamże. Zob. też: J. Giedroyc, A. Janta-Połczyński, Korespondencja 1947-1974, opracował, przedmową i przypisami opatrzył P. Kądziela, Warszawa 2009, s.50-52..

${ }^{56}$ Tamże.

${ }^{57}$ AIL ML, J. Giedroyc do A. Janty-Połczyńskiego, 5 I 1949 r.

${ }_{58}$ Zob. M. Grydzewski, J. Lechoń, dz. cyt., s. 50-51, 228, 231-233; Samotność słowa. Z listów do Wacława Iwaniuka. Józef Wittlin, Kazimierz Wierzyński, Aleksan- 
nie ukrywając swojego oburzenia pomimo przyjaźni, jaka ich łączyła ${ }^{59}$. Aleksander Janta pomagał m.in. w sprowadzeniu rzeczy poety z mieszkania paryskiego. Reakcja J. Lechonia dotknęła publicystę, który po latach jeden z rozdziałów swej autobiograficznej książki zatytułował: Dzieje przyjaźni i zdrada. Stwierdzał tam: „Miałem przekonać się później, że Lechoń wyjazd mój uznał za przestępstwo wobec narodu i w tym duchu urabiał przeciwko mnie opinię aż póki na dwa tygodnie przed śmiercią nie zatrzymał mnie na ulicy Nowego Jorku i nie wyciagnął do zgody i zapomnienia zarzutu, że popełniłem zdradę, tej samej ręki, której podania odmówił mi publicznie i ostentacyjnie po powrocie z Polski" 60 .

Zaraz po przeczytaniu pierwszego fragmentu reportażu J. Lechoń napisał M. Grydzewskiemu w końcu sierpnia 1948 roku: „,zdaje się, że Janta okazał się ostatecznie zdrajcą i skurwysynem - pod maską absurdyzmu" ${ }^{1}$. Redaktor "Wiadomości” przyznał poecie rację ${ }^{62}$. Niedługo, z końcem listopada, w podobnym tonie wyrażał swoje zdziwienie: „Czy Giedroyc zwariował umieszczając Jantę? Przecież to jest najwredniejszy zdrajca - bo na dwie strony kręci swoją zasraną dupą i na dwóch stołkach chce siedzieć. Jak w ogóle może być jakaś przyzwoitość moralna zachowana, jeżeli 2. Korpus puszcza się na takie perwersje" ${ }^{63}$. Natomiast po przeczytaniu całości J. Lechoń zdecydował się 29 maja 1949 r. napisać osobiście: „Pasterski List Jana Lechonia do Redaktora «Kultury» w sprawie Janty, Florczaka et consortes". Poinformował o tym M. Grydzewskiego poprzez streszczenie listu. Planował również wysłać jego odpis Zygmuntowi Nowakowskiemu, ale na przeszkodzie stanęła J. Lechoniowinieumiejętność pisania na maszynie ${ }^{64}$.

Jerzy Giedroyc zaraz pisał Aleksandrowi Jancie: „Dostałem list-posłanie od Lechonia na dwudziestu stronach [sic!], gdzie nawołuje mnie do zawrócenia ze złej drogi, na którą wszedłem drukując Pana, Florczaka etc. Myślę, że mu nic nie odpowiem, tym bardziej że najlepszą odpowiedzią będzie bieżący numer czerwcowy z nowym artykułem Florczaka ${ }^{65}$. Swo-

der Janta-Połczyński, oprac. Leszek M. Koźmiński, Lublin 1995, s. 124-125, 127-128. Po latach A. Janta powrócił do tej sprawy w swojej książce Nowe odkrycie Ameryki (s. 108). Opublikował w niej trzy inne listy dotyczące reportażu, otrzymane od Cz. Miłosza, A. Bobkowskiego i K. Wierzyńskiego. Zob. też Janta. Człowiek i pisarz, red. Jerzy R. Krzyżanowski, Londyn 1982.

${ }^{59}$ Zob. B. Dorosz, O Lechoniu i Grydzewskim..., s. 51; F. Palowski, dz. cyt., s. 90.

${ }^{60}$ A. Janta, Nowe odkrycie Ameryki, s. 106.

${ }^{61}$ M. Grydzewski, J. Lechoń, dz. cyt., s. 203.

${ }^{62}$ Zob. tamże, s. 206.

${ }^{63}$ Tamże, s. 214.

${ }^{64}$ Zob. tamże, s. 228.

${ }^{65}$ Chodzi o tekst Z. Florczaka Podróż na horyzonty [przypis mój-M. P.]. 
ją drogą nie rozumiem, dlaczego Panu mimo wszystko zależy na dobrych stosunkach z takimi typami. Podejrzewam o kompleks „Wiadomości” tak niestety rozpowszechniony"66. Aleksander Janta odpisał natychmiast i radził Redaktorowi: „Niech mu [J. Lechoniowi] Pan k o n i e c z n i e odpisze. To bardzo ważne, bo najważniejszym przeciwnikiem mojej akcji na rzecz „Kultury” jest właśnie on. A mnie niech Pan łaskawie dostarczy kopię swojej odpowiedzi i możliwie także tekst nawracań Lechonia abym wiedział, w co pruje i odpowiednio do tego kierował swoją akcją" ${ }^{67}$.

Aleksander Janta w kolejnych listach dopytywał się o ewentualną odpowiedź J. Giedroycia i przesłanie kopii [wiadomości otrzymanej od J. Lechonia]. W końcu lipca Redaktor zadecydował: „Na Lechonia jak również na ostatni atak Grydzewskiego na mnie i Florczaka zdecydowałem się nie odpowiadać. Coraz więcej mam potwierdzeń, że to Grydzewski aranżuje całą tą kampanię, gdyż boi się „konkurencji” "Kultury»" ${ }^{6}$. Publicyście nie spodobało się takie postawienie sprawy i przekonywał J. Giedroycia, iż bardzo źle robi, nie odpierając zarzutów poety. Jednocześnie dopominał się o przesłanie kopii listu ${ }^{69}$. Po jej otrzymaniu raz jeszcze próbował namówić J. Giedroycia do reakcji - proponował, by odpowiedni tekst do „Kultury” napisał J. Czapski ${ }^{70}$. Redaktor się sprzeciwił: „Jeśli idzie o Lechonia, to nadal się z Panem nie zgadzam. Naprawdę nie warto na niego reagować. Tak samo nie mam zamiaru reagować na pokasywania Grydza. Natomiast w numerze wrześniowym zamieszczam właściwie nie artykuł, a broszurkę Melchiora Wańkowicza ${ }^{71}$, która jest pewnym podsumowaniem problemu Bobkowski-Janta-Florczak, moim zdaniem znakomitym. To jest dopiero ładunek dynamitu podłożony pod emigrację. Przy całym moim zamiłowaniu do ryzykownych tematów i szokowania opinii długo i naprawdę ciężko decydowałem się na druk, ale uważam to za konieczne. To będzie najlepsza odpowiedź.

Jeśli idzie o Lechonia, to myślę, że najlepszą odtrutką na tego Mickiewicza dla ubogich będzie pobyt Józia [Czapskiego] w Stanach. Niech Pan mi wierzy, że czasami milczenie jest bardziej zabójcze od dyskutowania" ${ }^{72}$.

${ }^{66}$ AIL ML, J. Giedroyc do A. Janty-Połczyńskiego, 9 VI 1949 r.

${ }^{67}$ Tamże, A. Janta-Połczyński do J. Giedroycia, 13 VI 1949 r.

${ }^{68}$ Tamże, J. Giedroyc do A. Janty-Połczyńskiego, 28 VIII 1949 r.

${ }^{69}$ Tamże, A. Janta-Połczyński do J. Giedroycia, 4 VIII 1949 r.

${ }^{70}$ Tamże, A. Janta-Połczyński do J. Giedroycia, 24 VIII 1949 r.

${ }^{71}$ Mowa o tekście M. Wańkowicza Klub Trzeciego Miejsca („Kultura”, 6(23):1949, s. 5-83; wydanie osobne - Paryż 1949) [przypis mój - M. P.].

${ }^{72}$ AIL ML, J. Giedroyc do A. Janty-Połczyńskiego, 1 IX 1949 r. 
Jerzy Giedroyc napisał list do Nowego Jorku do Anieli Mieczysławskiej, u której J. Czapski miał zatrzymać się w trakcie pobytu w Stanach i która pozostawała także w bardzo dobrych relacjach z J. Lechoniem: „Nigdy nie broniłem poglądów czy ocen Janty. Drukowałem je w «Kulturze», czy potem wydałem w książce, gdyż za najważniejsze niebezpieczeństwo uważam, by ideałem Polski na emigracji nie stała się Polska przedwrześniowa. To już nie istnieje. Jeśli prowadzi się politykę i jest [się] na emigracji, to najważniejszym zadaniem jest obserwowanie przemian zachodzących w kraju. Ma się rozumieć, trzeba te rzeczy dyskutować publicznie" 73 .

Redaktor nie odpowiedział na list poety, powiadamił jednak o otrzymaniu korespondencji m.in. A. Bobkowskiego i M. Wańkowicza. Sprawę uznał za zamknięta ${ }^{74}$. Inaczej tę kwestię potraktował J. Lechoń, który powracał co pewien czas do tego sporu w Dzienniku. Po otrzymaniu wrześniowego numeru pisma zanotował: „Muszę zawsze skupiać w sobie całą moją bardzo jeszcze kulejącą olimpijskość, aby się nie wściekać. Pół numeru to kolubryna Wańkowicza, pasowana przez redakcję od razu na wieczyste pióro"75, by miesiąc później stwierdzić: „Prawdziwa furia na Wańkowicza, Czapskiego, Giedroycia i całą „Kulturę” nie opuszcza mnie prawdopodobnie dlatego, że poza listem do Giedroycia, na który on nie raczył zresztą odpowiedzieć - nie odreagowałem właściwie tych spraw. W gruncie rzeczy uważam, że napisać by o tym koniecznie trzeba - i jeśli tego nie czynię, to z najzwyklejszej wygody, nie chcąc babrać się $\mathrm{w}$ awanturę, w której wypuszczono by mnie na jakiś pętaków, a ja albo musiałbym się ośmieszać broniąc, albo zamilkłbym, uchodząc za pobitego" ${ }^{76}$. W kwietniu 1950 r. poeta pisał: „Chodziło o to, żeby pobić bolszewików. A później zrobić świat najbardziej możliwie podobny do sprawiedliwego i chrześcijańskiego. To chyba jasne. [...] Już chciałem zmusić się, aby czytać „Kulturę”, i nie mogę. Ten obiektywizm to czerwona płachta na mnie" 77 .

Sprawa A. Janty zbiegła się z coraz większym rozczarowaniem J. Giedroycia władzami polskimi na uchodźstwie oraz działaniami partii politycznych na emigracji. Po dymisji rządu gen. Tadeusza Bora-Komorowskiego na początku lutego 1949 r. Redaktor zdecydował się przedstawić koncepcję „ostatniej, niezgranej jeszcze drogi kontynuowania pracy

${ }^{73}$ Tamże, J. Giedroyc do A. Mieczysławskiej, 20 VII 1949 r.

${ }^{74}$ Zob. J. Giedroyc, A. Bobkowski, Listy 1946-1961, oprac. Jan Zieliński, Warszawa 1997, s. 105; J. Giedroyc, M. Wańkowicz, dz. cyt., s. 87.

${ }^{75}$ J. Lechoń, Dzienniki, t. 1, oprac. Roman Loth, Warszawa 1992, s. 61.

${ }^{76}$ Tamże, s. 67.

77 Tamże, s. 269. 
niepodległościowej w ramach legalizmu"78. Napisał w tej sprawie listmemoriał do gen. Kazimierza Wiśniowskiego, zakończony deklaracją: „Nie wiem jeszcze, jakie będę miał możliwości pracy, ale jestem zdecydowany za wszelką cenę utrzymać «Kulturę» i zrobić z niej podstawę swej pracy i trybunę polityczna, w której z grupa swoich przyjaciół będę próbował tworzyć współczesną myśl polityczną polską"79. Nie otrzymawszy odpowiedzi, wyznał A. Jancie: „Obecnie szykuję swoje rozejście się z Londynem. Nie chcę być źle zrozumiany. Nadal uznaję symbol legalizmu w obowiązującej konstytucji (której zresztą jestem zwolennikiem), osobie prezydenta i Insp[ektora] Gen[eralnego] [Sił Zbrojnych], ale już rząd mnie nic nie obchodzi. Rozpoczynam robotę na własny rachunek" $"$.

Generał Anders ustosunkował się do propozycji Redaktora w osobnym liście, skierowanym jednak do Czapskiego, gdzie tłumaczył: „czytałem memoriał Giedroycia, z którym Ty się solidaryzujesz. Proszę mi wierzyć, że doceniam i to niezwykle silnie, Wasze troski i poważne ujęcie Waszej Sprawy. Nie jestem w stanie w kilku słowach na to odpowiedzieć. Nie dałoby się nawet na to odpowiedzieć kontr-memoriałem. Te sprawy można tylko przedyskutować i nawzajem się zrozumieć. Dlatego też cieszę się niezmiernie, że przyjedziesz wkrótce do Londynu i będę miał możność wówczas, poza zawsze dla mnie miłym widzeniem Ciebie, wyjaśnić Ci mój punkt widzenia i ustalić pewne zasadnicze punkty"81.

O efektach wizyty J. Czapskiego nad Tamizą Redaktor doniósł A. Bobkowskiemu: „Józio wrócił z Londynu, gdzie nic nie wskórał i gdzie w rezultacie polecono mu zlikwidować placówkę i «K u $1 \mathrm{t}$ u r ę». Placówkę contre coeur, a «Kulturę» $\mathrm{z}$ satysfakcją. Ma się rozumieć w odpowiedzi na to, wysławszy dziękczynne pismo za dotychczasową pomoc, wywiesiłem czarną choragiew anarchii i niezależności" ${ }^{82}$. Zaś w wakacyjnym numerze miesięcznika Redakcja ogłosiła, iż „od 1 lipca 1949 r. «Kultura» będzie wychodziła na własne ryzyko" ${ }^{83}$.

\footnotetext{
${ }^{78}$ AIL ML, J. Giedroyc do gen. K. Wiśniowskiego, 21 III 1949 r.

${ }^{79}$ Jak wyżej. Wcześniej zostały uregulowane wszelkie zobowiązania Instytutu wobec wojska - zob. M. Ptasińska-Wójcik, $Z$ dziejów Biblioteki..., s. 70-72.

${ }^{80}$ AIL ML, J. Giedroyc do A. Janty-Połczyńskiego, 23 III 1949 r. Na przełomie 1948 i 1949 r. Instytut intensywnie zabiegał u władz francuskich o uzyskanie licencji na wydawanie „Kultury”. Otrzymał ją m.in. dzięki powiązaniu z Libellą i dlatego na początku 1949 r. w miesięczniku wystapiła podwójna numeracja: w obrębie roku i ciągła. M. Ptasińska-Wójcik, Z dziejów Biblioteki «Kultury»..., s. 73.

${ }^{81}$ BCzart, Zbiory Józefa Czapskiego, gen. W. Anders do J. Czapskiego, 24 IV $1949 \mathrm{r}$.

${ }^{82}$ J. Giedroyc, A. Bobkowski, dz. cyt., s. 104.

${ }^{83}$ [Redakcja], ,Kultura”, 1949, nr 4/5 (21/22), s. 6.
} 
We wrześniu 1949 r. A. Janta thumaczył Wacławowi Iwaniukowi ostatnie wydarzenia: „Rozłam między młodzieżą i starszymi, że to dotyczy Lechonia, Wierzyńskiego, etc. Jest rzeczą dokonaną, oni myślą wstecz, my pójdziemy naprzód. Ale oni bronią się wszystkimi środkami i nie przebierają w nich. Mamy tego świeży i bolesny dowód w postaci listu Lechonia do „Kultury” z tak beznadziejnie bogoojczyźnianą interpretacja konieczności stania murem i nieschodzenia z platformy orientacji sprzed 1939 roku, że trudno się z tym pogodzić, bo trudno przypuszczać, żeby w zacietrzewieniu swym ludzie wielkich talentów dochodzili do zupełnego zamknięcia oczu na to, co się dzieje, a za to upierali się przy trwaniu w swoich snach, marzeniach i związanych z nimi ambicjach duchowego przewodzenia innym" ${ }^{84}$.

Dyskusję tę zamknęły na łamach „Kultury” słowa J. Mieroszewskiego sygnalizujące zmianę linii politycznej Redaktora za sprawą korespondenta londyńskiego pisma, de facto jej porte-parole od 1950 roku: „Na zakończenie chciałbym jeszcze zapewnić panów Wańkowicza i Florczaka, że owego «trzeciego» miejsca nie ma. Jest tylko miejsce tutaj albo po tamtej stronie «Żelaznej Kurtyny». [...] Owo «trzecie» miejsce jest fikcją i stworzono go chyba w myśl zasady: na kryzys fikcji - więcej fikcji!" ${ }^{85}$.

Oryginał ośmiostronicowego odręcznego listu Lechonia znajduje się w Dziale Rękopisów Biblioteki Narodowej w Warszawie, sygnatura: akc. 016101, t. 1. Trafił on do BN wraz z kolekcją po Aleksandrze Jancie-Połczyńskim, przekazaną przez wdowę po pisarzu Walentynę. Trudności z odczytaniem rękopisów Lechonia oraz losy części jego listów opisała skrupulatnie Beata Dorosz we wstępie do edycji korespondencji z Mieczysławem Grydzewskim. B. Dorosz przytoczyła także obszerne fragmenty listu do Giedroycia ${ }^{86}$. Słowa nieodczytane oznaczono - [...], podkreślenia - pismem rozstrzelonym ${ }^{87}$. 128.

${ }^{84}$ A. Janta-Połczyński do W. Iwaniuka, [w:] Samotność słowa. Z listów..., s. 127-

${ }^{85}$ J. Mieroszewski, Do Redaktora «Kultury», „Kultura”, 8(25):1949, s. 94.

${ }^{86}$ B. Dorosz, O listach Jana Lechonia i Mieczystawa Grydzewskiego, w. M. Grydzewski, J. Lechoń, Listy 1923-1956, t. I, s. 9-41, fragmenty: s. 232-233.

${ }_{87}$ Autorka składa podziękowania Jackowi Krawczykowi za pomoc w odczytaniu tego listu. 


\section{ANEKS}

\section{PASTERSKI LIST JANA LECHONIA DO REDAKTORA «KULTURY»W SPRAWIE JANTY, FLORCZAKA ET CONSORTES}

New York, 29 maja 1949

\section{Drogi Panie,}

List ten piszę do Pana w sprawie ogólnej, prawie jako „List do Redakcji” ale, będąc przekonany, że polemika, którą on zawiera przyczyniłaby się tylko do niepożądanego zamieszania i będąc miejscem wszelkich widowisk publicznych dyskusji, nie wyjaśniających niczego, proszę Pana aby treść tego listu pozostała między mną a Panem czy między mną, Panem a Czapskim ${ }^{88}$. Myślę, że w ten sposób cel jego zostanie osiagnięty.

Chciałem do Pana pisać zaraz po ukazaniu się w „Kulturze” reportażu Janty - ale kiedy dalsze jego artykuły zostały wstrzymane - uważałem tę wysyłkę za szczęśliwie niepotrzebną i z radością z niej zrezygnowałem.

Artykuł pana Florczaka ${ }^{89}$, uhonorowany pomieszczeniem go na pierwszym miejscu - zmienia, niestety, mój pogląd, stawiając mnie wobec faktu poparcia Janty przez „Kulturę”, faktu, do którego zdecydowanie ustosunkowałem się wewnętrznie. Nie jest dla mnie możliwe zataić tę moją reakcję przed Panem - tak jak byłoby mi bardzo ciężko publicznie w tej sprawie wystapić. Może więc Pan zechce ten list przeczytać jako list przyjacielski Polaka, dla którego takie czy inne myśli i uczucia Polaków

88 Józef Czapski (1896-1993) - malarz i pisarz, brał udział w wojnie polsko-bolszewickiej, w 1. 1924-1933 przebywał w Paryżu. W latach 1939-1941 więzień łagrów, uwolniony na mocy układu Sikorski-Majski. W latach 1941-1942 poszukiwał, z polecenia gen. Andersa, zaginionych oficerów polskich - zamordowanych w Katyniu. Szef Wydziału Propagandy Armii Polskiej na Wschodzie gen. Andersa, później Oddziału Kultury i Prasy 2 Korpusu Polskiego do 1944 roku. Szefował Samodzielnemu Wydziałowi Kultury i Prasy przy Delegaturze 2 Korpusu Polskiego do spraw Uzupełnień we Francji tzw. placówce paryskiej od maja 1945 r. do lata 1949 r. Współzałożyciel Instytutu Literackiego w Rzymie, po przeniesieniu do Francji zamieszkał razem z Zespołem w MaisonsLaffitte. Czapski kierował tzw. placówka paryską z ramienia władz wojskowych i cywilnych. AIL ML, Pismo Naczelnego Wodza gen. Wł. Andersa do majora J. Czapskiego, Londyn 1 V 1945; Tamże, Pismo Ministra Informacji i Dokumentacji Adama Pragiera do majora Józefa Czapskiego, Londyn 2 VII 1945.

${ }^{89}$ Z. Florczak, Examen libre, „Kultura”, 1949, nr 2/19, s. 3-12. Redaktor po otrzymaniu tekstu napisał autorowi: „Mam po raz pierwszy od wielu lat poczucie, że jest to artykuł do którego nie miałbym do dodania czy ujęcia, poczucia że ten artykuł mógłbym sam podpisać bez najmniejszych zastrzeżeń. Zamieszczam go w nrze majowym jako wstępny”. AIL ML, J. Giedroyc do Z. Florczaka, 13 IV 1947 r. 
są rzeczą bardzo istotną i ważną który nie szuka łamów polemisty, ale który bardzo chciałby być zrozumiany i może nawet wysłuchany przez nielicznych.

Muszę też powiedzieć Panu po prostu, że artykuł i książkę Janty uważam za napisane świadomie czy nieświadomie pod dyktando bolszewickie i że obrona jego w „Kulturze” wydaje mi się rzeczą w najwyższym stopniu gorszącą i bardzo szkodliwą dla i tak zdezorientowanej i zdemoralizowanej opinii polskiej na emigracji. Moja opinia o Jancie opiera się na pewnym talencie, który sobie przypisuję, instynktownego syntetyzowania - wrażeń z lektury. Oczywiście, że tę syntezę podjąłbym się cytatami obronić. Ale nie uważam tego za potrzebne. Na dwa lata przed tym zanim Tuwim oficjalnie przystał do tego wtenczas „Lublina” zerwałem $\mathrm{z}$ nim wieloletnią przyjaźń pisząc mu, że przeszedł on granicę tych różnic poglądów, które przyjaźń może wyrównać ${ }^{90}$.

Na mój prywatny użytek nie mam też żadnych wątpliwości co do znaczenia i wartości tego co napisał Janta. Nie chciałbym też popaść w taką perwersję aby się nad tym jeszcze zastanawiać. Sprawa Janty jest oczywiście o tyle różna, że Tuwim jest i zostanie na zawsze pomimo wszystko wielkim poetą a Janta jest i prawdopodobnie zostanie na zawsze drugorzędnym dziennikarzem. Tym mniej rozumiem stanowisko Pana i to honorowe miejsce jakie dali Panowie w „Kulturze” sprawie, która myślę powinna była być i mogła być szybko zapomniana.

${ }^{90}$ Julian Tuwim (1894-1953) - poeta, thumacz. Od 1939 roku na emigracji. Przez Rumunię, Francję i Portugalię dostał się do Brazylii w 1940, a następnie przybył do Nowego Jorku w 1941 roku. Podróż swą odbył na trasie Lizbona Rio de Janeiro odbył razem z Lechoniem, z którym przyjaźnił się od blisko ćwierćwiecza. Tu zaraz nawiązał kontakty z grupą Oskara Langego i z Polsko-Amerykańską Radą Robotnicza, opowiadając się za porozumieniem między Polską a ZSSR. W 1946 roku powrócił do Polski. Współpraca Tuwima z komunistami i poparcie sojuszu Polski z Sowietami przyczyniło się do zerwania przez Lechonia ich wieloletniej przyjaźni. W liście z $29 \mathrm{~V} 1942$ roku napisał m.in.: „Decyzję moją, bardzo dla mnie ciężka, powziąłem po głębokim namyśle, przekonany, że jak argumenty [Józefa] Wittlina, tak i inne również nie zdołają Cię sprowadzić z tej drogi, na której nigdy się nie spotkamy i na której oby Cię nie czekały rozczarowania, zbyt ciężkie dla Twojej w gruncie rzeczy zupełnie nieodpowiedzialnej natury. Zechciej przyjąć zapewnienie mego żalu, że wbrew mej woli tak kończy się nasza wieloletnia przyjaźń". List opublikowany [w:] A. Janta-Połczyński, Przyjemnie zapoznać, Londyn 1972, s. 202-203; B. Dorosz, Lechoń i Tuwim - dzieje trudnej przyjaźni, Warszawa 2004, s. 45-46. Oryginał w Muzeum Literatury w Warszawie, nr inw. 3074, archiwum Juliana Tuwima. Czesław Miłosz w swoim raporcie stwierdzał: „Julian Tuwim. Jest on nastrojony entuzjastycznie dla sprawy przemian społecznych w Polsce i wraca do kraju. Przyjął mnie bardzo serdecznie. Zrobił na mnie wrażenie człowieka ciężko chorego nerwowo, na pograniczu manii prześladowczej. Nie ma prawie żadnych kontaktów z amerykanami, do pism amerykańskich nie pisywał, przez Polonię był szczuty. Żyje w New Yorku jak na wyspie bezludnej, pogrążony w Puszkinie”. Archiwum MSZ, C. Miłosz, Sprawozdanie z czynności za czas od 7 II 1946-30 III 1946 z działu kultury i sztuki (poufne). 
Artykułu pana Florczaka, o którym zresztą nic nie wiem - po prostu nie rozumiem. Nie rozumiem jak można tak jak on pisać o Nowakowskim ${ }^{91}$, który mimo wszelkich swoich kaprysów jest jedną z niewielu trwałych i szlachetnych ideowo i pisarsko pozycji naszej emigracji, może po Matuszewskim $^{92}$ najtrwalszą. Być może Pan uzna to za arogancję kiedy powiem, że jestem pewny iż kilkanaście artykułów Nowakowskiego zostaną na zawsze jako ozdoba polskiej publicystyki i myśli politycznej. Czy pan Florczak na pewno przeminie bez echa tego nie wiem, ale jeśli chodzi o moje zdolności zrozumienia i odczucia polskiego słowa pisanego, to muszę stwierdzić, że dotychczas nie czytałem nic z jego podpisem co by nie było bądź niepotrzebnie zawikłane, bądź banalne, bądź jak to mówią „kulą w płot”.

Spowiadam się Panu najszczerzej: nie rozumiem jak można, pisząc tak jak pan Florczak, tak pisać o Nowakowskim. Oczywiście te wątpliwości mógłby ktoś przeciąć mówiąc, że ja się właśnie nie znam na pisaniu. Ten list do Pana piszę w złudnym może przeświadczeniu, że Pan nie jest tego zdania.

Myślę najszczerzej, że obrona pewnej hierarchii artystycznej i ludzkiej była zawsze wielką potrzebą polskiego życia, a na emigracji jest nią w dwójnasób. Dlatego również artykuł pana Florczaka uważam za gorszący, uważam go za objaw złych obyczajów; oczywiście dlatego, że najszczerzej cenię wysoko Nowakowskiego. Stosunek tego pana zarówno do tak, zdawało mi się, [niewątpliwych] wartości i zasług Nowakowskiego jak do żałosnej sprawy Janty wydaje mi się przecież objawem pewnej tendencji umysłowej, która, śmiem tak myśleć, odegrała już straszną rolę w poddaniu się na całym świecie „klerków” różnym „koniecznościom” i w zaprzepaszczeniu przez polskich intelektualistów wielkiej moralnej

${ }^{91}$ Zygmunt Nowakowski (1891-1963) - powieściopisarz, felietonista. Od 1939 na emigracji, najpierw Paryżu, a później w Londynie. Bliski współpracownik Grydzewskiego, na łamach „Wiadomości Polskich” publikował m.in. felietony polityczne. Florczak w artykule Examen libre skomentował krytyczne przyjęcie przez emigrację książki Janty, która jego zdaniem ,„poróżniła Polaków za granica, ale dyskusji nie było”. Szczególnie odniósł się do nieprzychylnej recenzji Nowakowskiego «Wielki Spowiednik», „Wiadomości”, 1949, nr 16/17 z 24 kwietnia. Doceniając „uwodzicielski” kunszt pióra Nowakowskiego, zarzucił mu, iż jego w felietonach, ,intelektualnego rytmu jest w tym nie więcej niż w numerze tanecznym. Ani punkt wyjścia, ani argumentacja nie mają w sobie tej konsystencji myślowej, która bolący, smutny łeb człowiekowi otwiera nieraz jak okno naprzeciw nieba. [...] Nowakowskiemu o merytoryczną cenę słowa nie chodzi, bo mu zależy na retorycznym rozkręceniu i roztańczeniu pióra”. (Z. Florczak, Examen libre..., s. 10).

92 Ignacy Matuszewski (1891-1946) - jeden z czołowych publicystów sanacji, minister skarbu 1929-1931, redaktor „Gazety Polskiej” (1932-1936). W czasie wojny w Stanach Zjednoczonych, zwalczał politykę wschodnią rządu gen. Sikorskiego. Stale współpracował z „Dziennikiem Polskim” w Detroit, „Nowym Światem” w Nowym Jorku. 
linii, która była nie tylko chlubą polskiej myśli ale jednym ze skarbów tak patetycznie mówiąc ,ppolskiej duszy”.

W swoim artykule o Wańkowiczu napisał Czapski, że zawsze go zastanawiała pewność jego ojca - że coś tak powinno być albo być nie powinno ${ }^{93}$. Uważam, że bez tej pewności nie byłoby ani Mickiewicza, ani Słowackiego, ani Péguy, ani Piłsudskiego. Krańcowym przeciwieństwem tego wygnańczego stosunku do życia (i literatury zreszta) jest relatywizm z najróżniejszych pobudek płynący, który chce wszystko rozpatrywać i rozumieć, choć przecież są rzeczy, nie wymagające ani dyskusji, ani dociekań i po prostu bijące w oczy. Jako powieściopisarz mogę analizować psychologię zdrady, ale jako publicysta muszę to pojęcie uważać za pewien absolut, z którym nie może być żadnych polemik tylko walka. „Kultura” z bardzo szlachetnych pobudek wzięła sobie zdaje się za zdanie - „nie odchodzić od kraju". Rozumiem i cenię to pragnienie - ale jego realizacja zdaje mi się niemożliwa i nieraz niebezpieczna. Po cichu możemy sobie powiedzieć, że „kraj” to już, jeśli chodzi o literaturę, nie jest nie tylko Żeromski ${ }^{94}$ ale i Kaden ${ }^{95}$, że „kraj” to jest Nałkowska ${ }^{96}$, Pruszyński ${ }^{97}$, Breza $^{98}$. Staff ${ }^{99}$ na pewno nie myśli, że „odszedłem od niego” dlatego, że nie drukuję u „Czytelnika” ${ }^{100}$, na pewno myśli wręcz przeciwnie. A jak „nie odejść” od prymusowego świństwa Iwaszkiewicza ${ }^{101}$ czy

\footnotetext{
${ }^{93}$ J. Czapski, Mel, „Kultura” 1949, nr 16/17, s. 204-213.

${ }^{94}$ Stefan Żeromski (1864-1925) - powieściopisarz, nowelista, dramaturg, publicysta.

95 Juliusz Kaden-Bandrowski (1885-1944) - pisarz, publicysta, organizator życia literackiego.

${ }^{96}$ Zofia Nałkowska (1884-1954) - powieściopisarka, autorka dramatów, publicystka.

${ }^{97}$ Ksawery Pruszyński (1907-1950) - pisarz, publicysta.

${ }_{98}$ Tadeusz Breza (1905-1970) - pisarz, eseista.

${ }^{99}$ Leopold Staff (1878-1957) - poeta, dramatopisarz, thumacz.

${ }^{100}$ Spółdzielnia Wydawnicza „Czytelnik” założona w 1944 roku z inicjatywy Jerzego Borejszy. Wydawała literaturę piękną polską i obca, eseistykę, pamiętnikarstwo, epistolografię, publicystykę i szeroko rozumianą literaturę faktu, książki dla dzieci i młodzieży.

${ }^{101}$ Jarosław Iwaszkiewicz (1894-1980) - poeta, pisarz, dramaturg, eseista i thumacz. Lata wojny spędził w Stawisku, prowadząc z żoną otwarty dom dla artystów. Po wojnie włączył się aktywnie w życie literackie. W 1948 roku był przewodniczącym polskiego komitetu na Kongresie Intelektualistów w Obronie Pokoju we Wrocławiu. W latach 1947-1948 redagował „Nowiny Literackie”. Wszedł do zarządu polskiego Pen Clubu. W latach 1945-1949 sprawował funkcję prezesa Związku Zawodowego Literatów Polskich. Od 1949 roku był wiceprezesem Zarządu Głównego Związku Literatów Polskich, który powstał na bazie przedwojennego ZZLP w czasie zjazdu szczecińskiego, obradującego w dniach 20-23 stycznia. Zjazd ten, obok zmian organizacyjnych, dał podstawy przede wszystkim do narzucenia socrealizmu kulturze krajowej. Zob.: K. Woźniakowski, Między ubezwłasnowolnieniem a opozycja Zwiazek Literatów Polskich w latach 19491959, Kraków 1990.
} 
Gałczyńskiego ${ }^{102}$, czy Andrzejewskiego ${ }^{103}$ czy teraz nawet Żukrowskiego $^{104}$. Myślę, że to nasze zadanie - aby, jedząc bardzo ciężki chleb emigracji „odejść” od tego, co jest straszliwie narzuconym krajowi upodleniem. Przyznam się, że stanowisko „Kultury” w tych sprawach, których tu bezładnie i bardzo grubo dotykam - jest dla mnie szczerze ciężkim przeżyciem. Widzę w nim pewien fenomen, bardzo charakterystyczny dla ludzi, którzy sami mieli okazję i wolę coś poświęcić, coś moralnie pięknego zdziałać w życiu. Zdawałoby się, że taki dorobek - uzbraja człowieka w możność sądzenia twardo spraw i ludzi, co jest w naszym dzisiejszym życiu tak ważne i potrzebne. Panowie macie pewne prawa, których mnie na przykład bardzo łatwo odmówić. „Nie byłeś, nie cierpiałeś, nie masz prawa sądzić". Otóż może się mylę ale mam wrażenie, że wielu Polaków, którzy przeszli przez Rosję, wojnę, powstanie - czerpie z tego usprawiedliwienie do luksusu relatywizmu i pobłażania. Mnie nikt nic nie będzie mógł zarzucić, ja mogę pobłażać - bo mam za sobą rany, obozy, podziemie". Myślę, że Pan mnie dobrze zrozumie, że Pan nie wątpi na chwilę, iż wiem, że u ludzi Pana i Pana przyjaciół typu ta tendencja jeśli się przejawia jest wyrazem najbardziej szlachetnych i subtelnych odruchów. Ale niech Pan pomyśli, że cały „pétainizm” wyrósł właściwie z tego, że Pétain uważał ,ja byłem pod Verdun, ja mogę się poddać" ${ }^{105}$. Przecież za Pétainem

${ }^{102}$ Konstanty Ildefons Gałczyński (1905-1953) - poeta. Został zmobilizowany do wojska w sierpniu 1939 roku. 17 września dostał się do niewoli. Wojnę spędził w niemieckich obozach jenieckich. Po wyzwoleniu przebywał przez pewien czas m.in. w Paryżu, Brukseli i Rzymie. Wrócił do Polski w 1946. Współpracował z „Przekrojem”, „Tygodnikiem Powszechnym”, „Odrodzeniem”. Po krótkim pobycie w Szczecinie w 1948 roku, gdzie władza komunistyczna stworzyła literatom idealne warunki do pracy twórczej, osiadł na stałe w Warszawie.

103 Jerzy Andrzejewski (1909-1983) - prozaik i publicysta. Współpracował z tygodnikiem „Odrodzenie” (1945-1950). Był prezesem Oddziału Krakowskiego ZLP w latach 1946-1947. Przeniósł się do Szczecina w 1948, gdzie obok pisarstwa aktywnie uczestniczył w Komitecie Obrony Pokoju oraz Towarzystwa Przyjaźni Polsko-Radzieckiej. W latach 1949-1952 był prezesem Oddziału Szczecińskiego ZLP i wiceprezesem ZG ZLP. Czesław Miłosz w Zniewolonym umyśle sportretował pod kryptonimami czterech pisarzy tj. Alfa - J. Andrzejewski, Beta - T. Borowski, Gamma - J. Putrament, Delta - K.I. Gałczyński, którzy ulegli „Nowej Wierze”.

${ }^{104}$ Wojciech Żukrowski (1916-2000) - pisarz, reportażysta, autor książek dla dzieci i młodzieży. W czasie wojny walczył m.in. w obronie Narwi, okres okupacji spędził w Krakowie. Był żołnierzem AK, współredagował z Kazimierzem Wyką konspiracyjny „Miesięcznik Literacki”. Po wyzwoleniu oficer Ludowego Wojska Polskiego. W latach 1945-1949 należał do redakcji tygodnika „Odra”.

${ }^{105}$ Philippe Pétain (1856-1951) - marszałek Francji; w czasie I wojny światowej wsławił się obroną Verdun przed Niemcami, która trwała do lutego do grudnia 1916 roku. W czerwcu 1940 roku podpisał akt kapitulacji Francji i pełnił funkcję szefa rządu w Vichy. Po wojnie został osądzony i skazany za kolaborację na karę śmierci, zamienioną na dożywotnie więzienie. 
poszedł nie tylko kanalia Drieu La Rochelle ${ }^{106}$ i szmata Chardonne ${ }^{107}{ }_{2}$ ale i szlachetny ale jakże relatywistyczny Valéry ${ }^{108}$ ! Ach! Jak by to było dobrze - żeby Pan uwierzył w głęboką i ważną przyjaźń, jaka mi dyktuje te słowa i każe snuć aż tak krańcowe parabole. Nasza emigracja - jest to nie zorganizowane ale coraz bardziej zdezorganizowane nieszczęście. Klęska literatury i sztuki jest w tym naszym strasznym życiu jednym z najcięższych przeżyć i najobrzydliwszych widowisk.

Nie mogę się już zmienić po pięćdziesiątce - wciąż sobie wyobrażałem, że paru ludzi zgromadzi się wokół paru prawd, nie do zachwiania i nie do dyskusji, prawd, których absolut jest według mego instynktu sensem tragicznym i najcięższym estetycznym smakiem życia. Artykuł pana Florczaka na czele „Kultury” jest daniem „łopata po głowie” tym marzeniom. Według moich pojęć i obyczajów gdyby Panowie umieścili w następnym numerze - polemikę z tym artykułem - nie zmieniłoby to nic w tej sprawie. Wyspiański, którego mógłbym i chciałbym jak Nowakowski cytować bez końca, powiada coś w tym rodzaju: „A! Naturalnie! Powinna być cenzura narodowa”. I boję się, że jeśli nie będzie cenzury oburzenia Nowakowskiego - to zostanie nam tylko cenz u ra R a d ki e w i c za ${ }^{109}$.

Proszę, drogi Panie, wierzyć moją prawdziwą przyjaźń i przyjąć bardzo serdeczne słowa dla siebie i Czapskiego, od

Jana Lechonia

PS

Mój adres:

Jan Lechoń

c/o Mrs Lehman

574 West 114 Street New York (NY)

${ }^{106}$ Pierre Drieu La Rochelle (1893-1945) - prozaik, poeta, dramaturg i publicysta francuski. Należał do najgorętszych „kolaboracjonistów”. W czasie II wojny światowej był redaktorem „Je suis partout” i „Nouvelle Revue Française”. Przyjął wraz z Jacques Chardonne zaproszenie Goebbelsa na udział w Kongresie Pisarzy Europejskich w Weimarze, w październiku 1942 roku.

107 Jacques Chardonne (1884-1968) - pisarz francuski. Zwolennik rządu w Vichy i współpracy z Niemcami.

${ }^{108}$ Paul Valéry (1871-1945) - poeta, eseista i krytyk francuski.

${ }^{109}$ Stanisław Radkiewicz (1903-1987) - działacz komunistyczny, w latach 1944-1954 minister bezpieczeństwa publicznego, członek Biura Politycznego KC PPR i PZPR. 


\section{Streszczenie}

\section{Na marginesie sporu wokół ksiażki Aleksandra Janty-Połczyńskiego Wracam z Polski. List Jana Lechonia do Jerzego Giedroycia z maja 1949 r.}

Przełom lat czterdziestych i pięćdziesiątych XX wieku był okresem kształtowania się strategii wydawniczej Jerzego Giedroycia po przeniesieniu Instytutu Literackiego z Rzymu do Paryża. Pierwszoplanowe miejsce w działalności wydawnictwa zajął miesięcznik „Kultura”, na łamach którego dochodziło do różnych - miejscami gorących - sporów wokół linii politycznej pisma.

Publikacja pierwszej części reportażu Aleksandra Janty-Połczyńskiego Wracam z Polski 1948 w miesięczniku wywołała oburzenie gros uchodźstwa niepodległościowego. Unaoczniła różnice między ,polskim” Londynem a paryską „Kulturą” odnośnie stosunku do powojennej Polski. Na polecenie gen. Władysława Andersa pismo wycofano ze sprzedaży w Wielkiej Brytanii. Pod wpływem krytyki Redaktor wstrzymał dalszy druk reportażu w „Kulturze”. Całość w formie książki ukazała się jego nakładem na początku 1949 roku.

Giedroyc nie poparł wraz z zespołem „Kultury” uchwały Związku Pisarzy Polskich na Obczyźnie z czerwca 1947 roku, która de facto zakazywała twórcom emigracyjnym drukowania w kraju ,utworów swoich dawnych i nowych”. Sceptycznie odnosił się do poglądów prezentowanych m.in. przez londyńskie „Wiadomości” Mieczysława Grydzewskiego, odrzucające krajową rzeczywistość, krytykujące powroty rodaków, zwłaszcza pisarzy, do ojczyzny.

Niniejszy artykuł spowodował wymianę listów na przełomie października i listopada 1948 r. między Józefem Czapskim, gen. Andersem a Jerzym Giedroyciem. Każdy z nich zaprezentował własny punkt widzenia w tej kwestii, co jednak nie zbliżyło stron.

Jednak najostrzejszy w formie okazał się tzw. list pasterski Jana Lechonia do Giedroycia, który poeta wystosował do Redaktora „Kultury” po przeczytaniu książki w maju 1949 roku. Lechoń należał wówczas do najbliższych współpracowników Grydzewskiego i ,Wiadomości”. W liście napisanym w tonie bardzo emocjonalnym Lechoń zarzucił Jancie napisanie książki świadomie czy nieświadomie pod dyktando bolszewickie. Obrona pisarza w „Kulturze” wydała się poecie ,rzeczą w najwyższym stopniu gorszącą i bardzo szkodliwą dla i tak zdezorientowanej i zdemoralizowanej opinii polskiej na emigracji”.

Niniejszy list stanowi najlepszą wykładnie poglądów tzw. „niezłomnych” i ,nieprzejednanych" na kwestie stosunku emigracji niepodległościowej do Polski po 1945 roku.

Poeta nie otrzymał odpowiedzi od Giedroycia, który uznał sprawę za zamkniętą po opublikowaniu książki. 


\section{On the Dispute Following the Publication of the Book Wracam z Polski by Aleksander Janta-Połczyński: The Letter of Jan Lechoń to Jerzy Giedroyc (May 1949)}

After the transfer of Instytut Literacki from Rome to Paris, the break of the nineteen-forties and the nineteen-fifties turned out to be formation time for the editorial strategy of Jerzy Giedroyc. During these days, the monthly Kultura acquired the leading part in the activities of the Instytut, and in this role it published, fervent at times, polemics, concerning the political line of the periodical.

The printing of the first part of the documentary by Aleksander Janta-Połczyński "Wracam z Polski 1948" (Upon my return from Poland, 1948) was received with indignation by the majority of the Polish émigré milieu. It also revealed the differences in the attitude of the "Polish" London and the Parisian Kultura towards post-war Poland. Kultura, upon the instructions of General Anders, was withdrawn from sale in Great Britain. Under such pressure, Giedroyc refused to publish the second part of the documentary in Kultura, but, financed the edition of the complete book in early 1949.

Giedroyc, and the Kultura team, refused to support the June 1947 resolution of the Union of Polish Writers, which in reality prohibited the publishing of "older and current works" in Poland. Giedroyc was also sceptical of the stance assumed by the London based journal Wiadomości, directed by Mieczysław Grydzewski, which cut itself completely off from what was happening in Poland, and criticised the persons who decided to return home, in particular the writers.

The publishing of Janta's article resulted in an exchange of letters between Józef Czapski, General Władysław Anders, and Jerzy Giedroyc, in October and November 1948. Each of them presented his own views, but no compromise was reached. Nevertheless, the most vehement turned out to be the so called "Pastoral" letter by Jan Lechon to Jerzy Giedroyc, written by the poet, after having read the book in May 1949. At the time, Lechon belonged to the closest collaborators of Mieczysław Grydzewski and the London Wiadomości. In his highly emotional dispatch, Lechoń accused Janta of conscious, or unconscious, writing for the Bolshevik cause, and the defence of Janta's attitude by the Kultura milieu, in Lechon's eyes, was "most scandalising and extremely damaging with respect to the already disoriented and demoralised Polish émigré opinion". However, Giedroyc refused to respond to the letter. In his opinion, the publishing of Janta's book closed the issue.

Lechon's letter is one of the most representative texts for the "indomitable" and "uncompromising" wing of the Polish emigration after World War II. 